\begin{tabular}{l|l}
\hline Potaice & e-ISSN: 2655-9404 \\
Vol. 2 No. 3, Oktober 2019 & DOI: 10.20473/ntr.v2i3.16114 \\
\hline
\end{tabular}

Article history: Submitted 4 September 2019; Accepted 11 September 2019; Available online 1 October 2019.

\title{
Instrumen Pemulihan Kerugian Perusahaan terhadap Fraud Karyawan
}

\author{
Dimas Setio Wicaksono \\ dimas.setio@yahoo.co.id \\ Universitas Airlangga
}

\begin{abstract}
This research titled "Instrument for Recovery of Company Losses Against Employee Fraud". This type of research is normative juridical, which is research focused on examining the application of the rules or norms in positive law in force. In this study the problem formulation of the Company's Loss Recovery Instrument for Employee Fraud in the Civil Perspective and the Corporate Loss Recovery Instrument for Employee Fraud in the Corporate Governance Perspective. With the background Generally, each institution has different terms in referring to its human resources as mentioned above, but if defined employee / employee / labor is a term for people who work at an institution and get a wage. Even though it plays an important role in the company's business activities, employees can also be a source of company losses, negligence and carelessness of employees in carrying out their duties in accordance with their position and the use of company facilities that are not in accordance with their designation could potentially cause harm to the company. Results of research In the case of legal instruments for compensation of companies by filing lawsuits for unlawful acts to the court with the explanation as above, however, many companies tend to make internal resolutions, which incidentally by using inadequate legal instruments (with payment agreements without guarantee agreement or limited payment statement by employees), rather than making a settlement in court, or using other legal instruments available. And in Article 1365 BW where, whoever and whatever it is, when it causes a loss to another party, then it can be held accountable.
\end{abstract}

Keywords: Instrumen Losses; Fraud; Employe.

\begin{abstract}
Abstrak
Penelitian ini berjudul "Instrumen Pemulihan Kerugian Perusahaan Terhadap Fraud Karyawan". Tipe penelitian ini adalah yuridis normatif, yaitu penelitian di fokuskan untuk mengkaji penerapan kaidahkaidah atau norma-norma dalam hukum positif yang berlaku. Dalam penelitian ini menghasilkan rumusan masalah Instrumen Pemulihan Kerugian Perusahaan atas Fraud Karyawan dalam Perspektif Perdata dan Instrumen Pemulihan Kerugian Perusahaan atas Fraud Karyawan dalam Perspektif Tata Kelola Perusahaan. Dengan melatar belakang Umumnya tiap-tiap lembaga memiliki istilah berbedabeda dalam menyebut sumber daya manusia yang dimilikinya seperti tersebut diatas, namun jika didefinisikan karyawan / pegawai / tenaga kerja merupakan sebutan untuk orang yang bekerja pada suatu lembaga dan mendapatkan upah. Walaupun sangat berperan dalam kegiatan bisnis perusahaan, karyawan juga dapat menjadi sumber kerugian perusahaan, kelalaian maupun ketidak hati-hatian karyawan dalam mengemban tugas sesuai jabatannya dan penggunaan fasilitas perusahaan yang tidak sesuai dengan peruntukkannya berpotensi menimbulkan kerugian bagi perusahaan. Hasil dari penelitian Dalam hal instrumen hukum untuk penggantian kerugian perusahaan dengan mengajukan gugatan atas perbuatan melanggar hukum ke pengadilan dengan penjelasan sebagaimana di atas, namun banyak perusahaan cenderung untuk melakukan penyelesaian secara internal, yang notabene dengan memakai perangkat hukum yang kurang memadai (dengan perjanjian pembayaran tanpa perjanjian jaminan atau sebatas surat pernyataan membayar oleh karyawan), daripada melakukan penyelesaian di pengadilan, ataupun menggunakan instrumen hukum lain yang tersedia.
\end{abstract}

Kata Kunci: Instrumen Kerugian; Fraud; Karyawan. 


\section{Pendahuluan}

Setiap lembaga memiliki istilah berbeda-beda dalam menyebut sumber daya manusia yang dimilikinya, namun jika didefinisikan karyawan / pegawai / tenaga kerja merupakan sebutan untuk orang yang bekerja pada suatu lembaga dan mendapatkan upah. ${ }^{1}$ Menurut Prof. Isnaeni, ${ }^{2}$ jaminan umum yang berdasarkan Pasal $1131 \mathrm{BW}$ tersebut berfungsi sebagai penyangga perikatan dan atas hal ini diatur dalam Buku III BW. Meski begitu, Prof Isnaeni berargumen bahwa bangunan benteng yang ada pada Pasal 1131 BW belum mampu untuk dipertaruhkan sepenuhnya guna menyongsong derasnya arus kerugian yang dapat menerpa hubungan bisnis. Karakter jaminan umum dalam Pasal 1131 BW tersebut adalah bahwa jaminan tersebut dipergunakan oleh seluruh kreditor yang ada sehingga ada kalanya jumlah harta debitor tidak mampu untuk memenuhi jaminan masing-masing hutangnya kepada kreditor secara keseluruhan.

Walaupun sangat berperan dalam kegiatan bisnis perusahaan, karyawan juga dapat menjadi sumber kerugian perusahaan, kelalaian maupun ketidak hati-hatian karyawan dalam mengemban tugas sesuai jabatannya dan penggunaan fasilitas perusahaan yang tidak sesuai dengan peruntukkannya berpotensi menimbulkan kerugian bagi perusahaan. Suatu contoh kecil yang kerap terjadi yaitu penggunaan fasilitas kendaraan dinas untuk kepentingan pribadi, risiko yang mungkin timbul adalah terjadinya kecelakaan yang mengakibatkan mobil tersebut rusak sehingga nilai dari mobil tersebut sudah pasti akan berkurang, apabila terjadi hal tersbut maka wajar apabila perusahaan mengenakan ganti rugi terhadap karyawan tersebut, suatu contoh ekstrim yang kerap terjadi adalah adanya perbuatan melawan hukum berupa pencurian, penggelapan atau bahkan korupsi dimana perbuatan perbuatan tersebut jelas melanggar aturan-aturan hukum publik serta menimbulkan kerugian bagi perusahaan, kecurangan-kecurangan tersebut lazim disebut dengan Fraud, secara ringkas fraud berarti segala bentuk kejahatan untuk memperoleh keuntungan

1 Departemen Pendidikan Nasional, Kamus Besar Bahasa Indonesia (4th edn, Gramedia Pustaka Utama 2008).

2 Moch. Isnaeni, Pengantar Hukum Jaminan Kebendaan (LaksBang PRESSindo 2017).[101]. 
yang menggunakan kebohongan atau muslihat sebagai modus utamanya, sedikit lebih mendalam mengenai internal fraud menurut Association of Certified Fraud Examiners (ACFE), Internal Fraud atau yang disebut juga Occupational fraud didefinisikan sebagai, "the use of one's occupation for personal enrichment trough the deliberate misuse or misaplication of the organization's resources or assets ", 3 secara tidak resmi definisi tersebut diterjemahkan sebagai pemanfaatan suatu kedudukan atau jabatan untuk memperkaya diri sendiri dengan menyelahgunakan sumber daya atau aset organisasi (perusahaan).

Fraud atau kecurangan adalah suatu tindakan atau perbuatan yang dengan maksud di sengaja menggunakan sumber daya organisasi atau perusahaan secara tidak wajar untuk memperoleh keuntungan pribadi sehingga merugikan pihak organisasi atau perusahaan yang bersangkutan atau pihak lain. Berbicara mengenai Fraud dan Tindak Pidana tidak bisa di satukan dan di persepsikan adalah hal yang sama kecuali dari dampak yang di timbulkannya yaitu merugikan pihak lain (dalam hal ini perusahaan atau karyawan). Fraud sejatinya merupakan salah satu risiko melekat (inherent risk) dalam Risiko Operasional yang bersumber dari faktor Manusia. Sedangkan Tindak Pidana Perusahaan merupakan suatu perbuatan yang pelakunya di ancam hukuman pidana berdasarkan Undang-Undang. Unsur dari tindak pidana adalah subjek (pelaku) dan wujud perbuatan baik yang bersifat positif yaitu melakukan suatu perbuatan, maupun negatif yaitu tidak melakukan suatu perbuatan yang wajib dilakukan. Terdapat empat faktor pendorong seseorang untuk melakukan kecurangan, yang di sebut juga dengan teoriGONE, yaitu Greed (keserakahan), Opportunity (kesempatan), Need (kebutuhan), Exposre (pengungkapan). Faktor Greed dan Need merupakan faktor yang berhubungan dengan individu pelaku kecurangan (disebut juga faktor individual). Sedangkan faktor Opportunity dan Exposure merupakan faktor yang berhubungan dengan organisasi sebagai korban perbuatan kecurangan (disebut juga faktor generik/ umum).

\footnotetext{
3 Association of certified fraud examiners (ACFE), "What Is Fraud"” (Association of certified fraud examiners (ACFE), 2017).
} 
Pihak yang terkait dalam mencegah dan mendeteksi serta menangani fraud : yaitu akuntan (baik sebagai auditor internal, auditor eksternal, atau auditor forensik) dan manajemen perusahaan. ${ }^{4}$ Keberhasilan kegiatan memerangi fraud, setelah korupsi terjadi adalah suatu ironi tersendiri dalam upaya penanggualan fraud karena semakin banyak mendeteksi dan menyelesaikan kasus berindikasi fraud, bukan merupakan kondisi umum yang di kehendaki masyarakat, sebab pada dasarnya kejadian fraud bukanlah kejadian yang di kehendaki masyarakat. Pencegahan fraud bisa di analogikan dengan penyakit, yaitu lebih baik di cegah dari pada diobati. Jika menunggu terjadinya fraud baru ditangani itu artinya sudah ada kerugian yang terjadi dan telah dinikmati oleh pihak tertentu, bandingkan bila kita berhasil mencegahnya, tentu kerugian belum semuanya beralih ke pelaku fraud tersebut. Dan bila fraud sudah terjadi maka biaya yang dikeluarkan jauh lebih besar untuk memulihkannya daripada melakukan pencegahan sejak dini.

Untuk melakukan pencegahan, setidaknya ada tiga upaya yang harus dilakukan yaitu (1) Membangun individu yang didalamnya terdapat trust and openness, mencegah benturan kepentingan, confidential disclosure agreement dan corporate security contract. (2) Membangun sistem pendukung kerja yang meliputi sistem yang terintegrasi, standarisasi kerja, aktifitas control dan sistem rewards and recognition. (3) Membangun sistem monitoring yang didalamnya terkandung control self sssessment, internal auditor dan eksternal auditor. ${ }^{5}$

Menurut J.H. Nieuwenhuis,tanggung gugat timbul karena adanya perbuatan melanggar hukum (onrehmatige daad) dan merupakan penyebab (oorzaak) timbulnya kerugian. ${ }^{6}$ Perbuatan melawan hukum (Onrechmatige daad) diatur dalam Pasal 1365 BW. Pasal ini menetapkan bahwa perbuatan yang melawan hukum mewajibkan orang yang melakukan perbuatan itu, jika karena kesalahannya telah

\footnotetext{
4 Harry Andrian Simbolon, 'Mengupas Seluk Beluk Fraud Dan Cara Mengatasinya' (Akuntansiterapan.com, 2010) <https://akuntansiterapan.com/2010/12/22/mengupas-seluk-beluk-fraud-dan-cara-mengatasinya/> accessed 1 August 2019.

5 Arif Arryman et.al, Mengupas Benang Kusut, Merajut Masa Depan (Transformasi Tata Kelola Pelaporan Keuangan Telkom Pasca SOA 2010).

6 Siti Kotijah, 'Tanggung Gugat Hukum Perusahaan Akibat Pengelolaan Pertambangan Batubara’ (2011) 26 Yuridika.
} 
timbul kerugian, untuk membayar kerugian itu. Pasal 1365 BW menyatakan:

"Tiap perbuatan melanggar hukum yang membawa kerugian kepada orang lain, mewajibkan orang yang karena salahnya menerbitkan kerugian itu, mengganti kerugian tersebut."

Sedangkan ketentuan pasal 1366 BW menyatakan:

"Setiap orang bertanggung-jawab tidak saja untuk kerugian yang disebabkan karena perbuatannya, tetapi juga untuk kerugian yang disebabkan karena kelalaiannya atau kurang hati-hatinya."

Karyawan perusahaan juga alangkah baiknya memperhatikan tentang keseimbangan para pihak dalam berkontrak merupakan konsep dasar yang bersifat imperatif dari pemahaman prinsip equality before the law, hal ini harus selalu menjadi acuan dalam tiap-tiap penerapan azas kebebasan berkontrak, sebagaimana di tegaskan dalam pasal 1338 BW. Kebebasan berkontrak selalu melahirkan konsekuensi, bahwa kontrak yang akan dibuat selalu berlandaskan pada dua kepentingan yang tidak sama dan mengarah pada tujuan yang sama yaitu pemenuhan prestasi. Acapkali dalam kebebasan berkontrak yang notabene dilandasari semangat liberalisme yang mengagungkan individu, juga dipengaruhi semboyan dalam revolusi Perancis "liberte, egalite et fraternite" ${ }^{77}$ dengan akibat memberi peluang kepada golongan ekonomi kuat untuk menekan dan mengalahkan golongan ekonomi lemah.

Para pihak yang terlibat dalam dunia perusahaan ingin agar segala sesuatunya dapat berjalan sesuai dengan apa yang di rencanakan. Akan tetapi, dalam praktik ada kalanya apa yang telah di setujui oleh kedua belah pihak tidak dapat di laksanakan karena salah satu pihak mempunyai penafsiran yang berbeda dengan apa yang telah di setujui sebagaimana yang tercantum dalam kontrak sehingga dapat menimbulkan perselisihan.

Berdasarkan uraian yang menjadi latar belakang ini, maka masalahmasalah yang di angkat penulis dalam usulan penelitian ini adalah instrumen pemulihan kerugian perusahaan atas fraud karyawan dalam perspektif perdata

\footnotetext{
${ }^{7}$ Agus Yudha Hernoko, Hukum Perjanjian Asas Proporsionalitas Dalam Kontrak Komersial (Prenada Media Group 2014). diedit oleh Sarwirini dan Budi Kagramanto, Puspa Ragam Informasi Dan Problematika Hukum (Karya Abditama 2000).[99].
} 
dan instrumen pemulihan kerugian perusahaan atas fraud karyawan dalam perspektif tata kelola perusahaan.

\section{Instrumen Pemulihan Kerugian Perusahaan Atas Fraud Karyawan Dalam Perspektif Perdata}

Ganti rugi secara umum diatur dalam norma hukum yang bertujuan untuk melindungi kepentingan-kepentingan harta kekayaan. Di samping norma-norma tertulis seperti larangan pencurian, penggelapan, dan sebagainya, perlu diperhatikan aturan-aturan tidak tertulis seperti larangan untuk meniru produk orang lain, membuat iklan yang merusak dan seterusnya. ${ }^{8}$ Selain diatur dalam norma hukum pidana, suatu perikatan yang banyak bersumber dari perjanjian, juga menciptakan norma hukum (kewajiban berprestasi) yang dapat melindungi pihak lain atau kreditur.

Pelanggaran norma-norma hukum seperti perbuatan melanggar hukum dan wanprestatie, lazimnya berakibat kerugian yang ditimbulkan akan dibebankan kepada pelanggar. Dalam kaitannya dengan ganti rugi berdasarkan norma hukum perdata, maka pembahasan akan dibatasi pada ganti rugi yang timbul dari perikatan dan dari perbuatan melanggar hukum.

Pengertian kerugian sebagaimana disampaikan Niuwenhuis adalah berkurangnya harta kekayaan pihak yang satu, yang disebabkan oleh perbuatan (melakukan atau membiarkan) yang melanggar norma oleh pihak yang lain. ${ }^{9}$

Berbicara mengenai tuntutan ganti kerugian secara Hukum Perdata, maka yang menjadi dasar tuntutannya adalah Wanprestasi atau Pasal 1365 BW untuk Perbuatan Melanggar Hukum. Demikian pula dalam pasal-pasal lainnya, diatur juga ganti kerugian tersebut, antara lain Pasal 1367, 1370, 1371, dan 1372 BW. Pasalpasal tersebut mengatur mengenai ganti kerugian khusus, yakni ganti kerugian khusus terhadap kerugian yang timbul dari perikatan-perikatan tertentu.

Lebih mendalam atas ganti kerugian dalam hukum perdata, dapat dibagi ke dalam dua jenis, yaitu ganti kerugian wanprestasi atau cidera janji dan ganti

\footnotetext{
8 MR JH Niewenhuis, Pokok Pokok Hukum Perikatan (Surabaya 1985). [57].

9 ibid.
} 
kerugian perbuatan melanggar hukum $(\mathrm{PMH})$. Perbedaan dari keduanya adalah sebagai berikut: ${ }^{10}$

1. Ditinjau dari sumber terjadinya:

a. Wanprestasi:

- Timbul dari perikatan akibat perjanjian.

- Harus ada perjanjian antara kedua belah pihak, menurut syarat sahnya perjanjian.

- Penggugat cukup menunjukkan adanya wanprestasi atau adanya perjanjian yang dilanggar.

- Terjadinya sejak lewat waktu yang disepakati dalam perjanjian.

b. $\mathrm{PMH}$ :

- Timbul dari undang-undang karena perbuatan yang dilarang.

- Penggugat harus membuktikan semua unsur perbuatan melanggar hukum termasuk adanya unsur kesalahan yang di perbuat tergugat.

- Terjadinya sejak perbuatan yang di lakukan oleh orang atau badan hukum menimbulkan kerugian bagi pihak lain.

2. Ditinjau dari bentuknya:

a. Wanprestasi: Keterlambatan, tidak sesuai dengan isi perjanjian atau tidak melaksanakan perjanjian, melakukan yang menurut perjanjian dilarang.

b. PMH: Perbuatan melanggar kewajiban hukumnya, atau melanggar hak subjektif orang lain, atau melanggar kesusilaan atau melanggar kepatutan, ketelitian, dan kehati-hatian.

3. Ditinjau dari timbulnya hak menuntut:

a. Wanprestasi: Diawali dengan adanya pernyataan atau peringatan lalai dengan teguran (somasi) dari kreditur.

b. PMH: Tidak perlu adanya peringatan atau teguran berupa somasi. Begitu terjadi kerugian akibat $\mathrm{PMH}$, maka langsung timbul hak untuk menuntut ganti kerugian.

4. Ditinjau dari tuntutan ganti kerugian:

a. Wanprestasi:

- Perhitungan ganti kerugian dihitung sejak terjadinya kelalaian.

- Jenis dan jumlah ganti kerugian telah diatur secara rinci oleh Pasal 1246 BW, yaitu: Kerugian yang di derita kreditur; Keuntungan yang akan diperoleh seandainya perjanjian di laksanakan sebagaimana mestinya; Ganti kerugian bunga.

${ }^{10}$ Evalina Yessica, 'Karakteristik Dan Kaitan Antara Perbuatan Melawan Hukum Dan Wanprestasi' (2014) 1 Repertorium. 
- Harus terinci.

b. PMH:

- Perhitungan ganti kerugian di hitung sejak saat di ajukan gugatan PMH.

- Sesuai dengan ketentuan Pasal 1365 BW.

- Dapat pula diperhitungkan jumlah ganti kerugian berupa pemulihan keadaan.

- Penggantian kerugian dinilai menurut kedudukan dan kemampuan kedua belah pihak, dan menurut keadaan.

- Penilaian terhadap besarnya ganti kerugian tergantung pada kebijaksanaan hakim.

5. Ditinjau dari akibat akhirnya:

a. Wanprestasi: Pelaksanaan prestasi dan/atau ganti kerugian.

b. PMH: Pemulihan keadaan seperti semula dan/atau ganti kerugian.

Kedudukan dari pihak yang terkena akibat dari perbuatan melanggar hukum berbeda dengan pihak yang terhadapnya telah dilakukan wanprestasi oleh kontraktan lawan. Dalam menandatangani suatu perjanjian atau kontrak, berarti pihak-pihak penandatangan telah mengetahui hak, kewajiban dan akibat serta risiko dari dibubuhkannya tanda tangannya tersebut, termasuk risiko kerugian yang terbit dari kontrak tersebut. Akan tetapi, lain halnya bagi pihak yang menderita atas akibat dari perbuatan melanggar hukum, yang sama sekali tidak pernah terpikir akan risiko dari perbuatan melanggar hukum, bahkan tidak terpikirkan sama sekali. Oleh karena pihak korban dari perbuatan melanggar hukum sama sekali tidak siap menerima risiko dan sama sekali tidak pernah berpikir tentang risiko tersebut, maka seyogianya dia lebih dilindungi, sehingga ganti kerugian yang berlaku kepadanya lebih luas dan lebih tegas berlakunya. ${ }^{11}$

Dari pembahasan di atas, timbul pertanyaan bagaimana dengan perusahaan sebagai korban dari fraud yang dilakukan oleh karyawan, apakah kedudukan perusahaan sebagai "korban" dari perbuatan melanggar hukum berupa fraud yang dilakukan oleh karyawan ini berhak mendapatkan ganti rugi yang lebih luas dan tegas berlakunya, yang merupakan pertanyaan yang hendak dijawab dalam

\footnotetext{
${ }^{11}$ Munir Fuady, Perbuatan Melawan Hukum (Pendekatan Kontemporer) (Citra Aditya Bakti 2005).[135-136].
} 
pembahasan di sini, termasuk instrumen hukum apa yang tersedia, "lebih luas" dan "lebih tegas" merupakan kata kunci yang hendak dicapai dalam pembahasan dan penulisan ini.

Dr. Trisadini dan Bakarbessy, ${ }^{12}$ sependapat dengan Prof. Isnaeni, mengatakan bahwa Pasal 1131 BW memberikan pengaturan jaminan yang bersifat umum, yaitu jaminan terletak pada harta debitor dan jaminan diberikan kepada seluruh kreditor. Artinya, kedudukan kreditor dengan jaminan umum hanyalah sebagai kreditor konkuren dan terhadap harta debitor tidak ada yang diutamakan dalam pelunasan, sekalipun diantara kreditor konkuren ada yang mempunyai tagihan yang lebih dahulu, sebagaimana diatur dalam Pasal 1132 BW, bahwa:

"Barang-barang itu menjadi jaminan bersama bagi semua kreditur terhadapnya hasil penjualan barang-barang itu dibagi menurut perbandingan piutang masing-masing kecuali bila di antara para kreditur itu ada alasan-alasan sah untuk didahulukan"

Melihat kelemahan yang didapatkan atas jaminan umum berdasarkan Pasal $1131 \mathrm{BW}$ tersebut, maka dalam hal penggantian kerugian perusahaan akibat fraud oleh karyawan yang harus diganti oleh karyawan tersebut, maka perusahaan tentu memilih membuat perjanjian jaminan menggunakan jaminan khusus yang objeknya adalah benda tertentu milik karyawan dan diperuntukkan bagi perusahaan. Jaminan kebendaan adalah jaminan atas benda tertentu milik debitor atau milik pihak ketiga yang diperuntukkan secara khusus bagi kepentingan kreditor tertentu pula. ${ }^{13}$ Kreditor pemegang jaminan kebendaan mempunyai kedudukan yang lebih baik karena: (i) kreditor didahulukan dan dimudahkan dalam mengambil pelunasan atas tagihannya atas hasil penjualan benda tertentu atau sekelompok benda tertentu milik debitor atau milik pihak ketiga; dan/atau (ii) Ada benda tertentu milik debitor atau pihak ketiga yang dipegang oleh kreditor dan terikat kepada hak kreditor, yang berharga bagi debitor dan dapat memberikan suatu tekanan psikologis terhadap debitor untuk

${ }^{12}$ Trisadini Prasastinah Usanti dan Leonora Bakarbessy, Hukum Jaminan (Revka Petra Media 2016).[13].

13 ibid.[17]. 
memenuhi kewajibannya dengan baik kepada kreditor. ${ }^{14}$

Pada umumnya ganti rugi diperhitungkan dalam sejumlah uang tertentu. Hoge Raad malahan berpendapat, bahwa penggantian "ongkos, kerugian, dan bunga" harus di tuangkan dalam sejumlah uang tertentu. Sering pula muncul pada tuntutan ganti rugi atas dasar onrechtmatige daad. Namun adanya ganti rugi atas kepentingan yang tidak dapat dinilai dengan uang, secara tegas-tegas di akui, seperti pada Pasal 1601 BW yang menyatakan bahwa:

"Jika salah satu pihak dengan sengaja atau karena salahnya telah berbuat melanggar dengan salah satu kewajibannya dan kerugian yang karenanya diderita oleh pihak lawan tidak dapat dinilaikan dengan uang, maka Hakim akan menetapkan suatu jumlah uang menurut keadilan, sebagai ganti rugi”.

Walaupun pembentuk undang-undang telah memberikan instrumen hukum untuk penggantian kerugian perusahaan dengan mengajukan gugatan atas perbuatan melanggar hukum ke pengadilan dengan penjelasan sebagaimana di atas, namun banyak perusahaan cenderung untuk melakukan penyelesaian secara internal, yang notabene dengan memakai perangkat hukum yang kurang memadai (dengan perjanjian pembayaran tanpa perjanjian jaminan atau sebatas surat pernyataan membayar oleh karyawan), daripada melakukan penyelesaian di pengadilan, ataupun menggunakan instrumen hukum lain yang tersedia. Hal ini dipengaruhi oleh beberapa faktor, menurut pengalaman yang ada, yaitu:

Pertama adalah rendahnya pengetahuan perusahaan dan karyawan atas hukum pada umumnya, atau hukum yang mengatur masalah ganti kerugian pada khususnya, sehingga aturan internal perusahaan pada umumnya tidak mengatur bagaimana karyawan harus mengganti kerugian perusahaan.

Kedua adalah pengaturan ganti kerugian dalam tata kelola perusahaan, di mana fraud control system belum ditetapkan secara hulu ke hilir, dalam artian bahwa upaya kontrol perusahaan hanya sebatas menetapkan apa itu fraud, unsurunsur fraud, serta sanksi adminitrasi atas fraud namun belum sampai mengatur ganti kerugian oleh karyawan dalam hal yang bersangkutan melakukan fraud.

14 ibid..[21] sebagaimana dikutip dari J Satrio, Hukum Jaminan, Hak Jmainan Kebendaan (4th edn, Citra Adtya Bakti 2002).[12]. 
Ketiga adalah prosedur cara penghitungan ganti kerugian dalam perusahaan, di mana perusahaan belum mengenali bagaimana cara perhitungan ganti kerugian yang dapat dipertanggungjawabkan di muka pengadilan. Dalam mengajukan ganti kerugian atas perbuatan karyawan, perusahaan umumnya mengajukan melalui gugatan atas perbuatan melawan hukum, namun lebih memilih menyelesaikan secara internal dengan prosedur yang bisa dibilang belum mempertimbangkan instrumen hukum yang tersedia.

\section{Instrumen Pemulihan Kerugian Perusahaan Atas Fraud Karyawan Dalam Perspektif Tata Kelola Perusahaan}

Di dalam mendirikan suatu perusahaan tentu tidak lepas dari tanggung jawab karena tanggung jawab merupakan salah satu kewajiban dari pelaku usaha terhadap konsumen, karyawan maupun lingkungan sekitarnya. Tanggung jawab secara definisi merupakan kesadaran manusia akan tingkah laku atau perbuatan baik yang disengaja maupun yang tidak disengaja, tanggung jawab juga berarti berbuat sebagai perwujudan kesadaran akan kewajiban. Tanggung jawab bersifat kodrati, yang artinya tanggung jawab itu sudah menjadi bagian kehidupan manusia bahwa setiap manusia dan yang pasti masing-masing orang akan memikul suatu tanggung jawabnya sendiri-sendiri. Apabila seseorang tidak mau bertanggung jawab, maka tentu ada pihak lain yang memaksa untuk tindakan tanggung jawab tersebut.

Segala kesasalahan atau kelalaian pelaku usaha yang dapat menimbulkan kerugian pada konsumen khususnya, atau kepada masyarakat umumnya haruslah bertanggung jawab atas kerugian yang di timbulkannya. ${ }^{15}$

Kerugian yang diderita oleh konsumen tidak selalu disebabkan oleh perusahaan, kerugian tersebut bisa saja terjadi karena kesalahan karyawan perusahaan yang dengan sengaja melakukan tindakan yang dapat merugikan konsumen demi keuntungan pribadi. Definisi dari kesalahan merupakan suatu tindakan atau perbuatan yang dilakukan oleh suatu individu atau sekelompok orang

${ }^{15}$ Zaeni Asyhadie, Hukum Bisnis Prinsip Dan Pelaksanaannya Di Indonesia (RajaGrafindo Persada (Rajawali Perss) 2012).[205]. 
yang di mana perbuatan tersebut dilakukan baik secara sengaja atau tidak sengaja yang berdampak buruk bagi orang yang dirugikannya. Manusia tidak lepas dari kesalahan, terkadang manusia sengaja melakukan kesalahan demi menguntungkan dirinya sendiri tanpa memikirkan kerugian yang diderita oleh orang yang di rugikan, tidak terkecuali kesalahan juga sering dilakukan oleh karyawan demi mendapatkan keuntungan dengan menggunakan profesinya. Pada dasarnya tindakan-tindakan karyawan telah diatur dalam aturan internal dalam perusahaan baik dalam bentuk peraturan perusahaan maupun kode etik dalam perusahaan, hal ini diperlukan agar karyawan tidak melakukan hal-hal yang dapat berdampak buruk bagi perusahaan, rekan kerja atau konsumen.

Berikut ini adalah jenis-jenis kesalahan karyawan:

1. Melakukan penipuan, penggelapan, pencurian barang atau uang milik perusahaan;

2. Memberikan keterangan palsu yang dapat merugikan karyawan;

3. Terlambat masuk kerja;

4. Sering bolos atau tidak masuk kerja;

5. Meminum-minuman keras atau memakai obat-obatan terlarang pada saat jam kerja atau dilingkungan kerja;

6. Dengan sengaja atau tidak membongkar rahasia perusahaan, dan lain-lain yang dapat merugikan perusahaan.

Kesalahan perusahaan tidak jarang disebabkan oleh faktor internal perusahaan, misal kesalahan tersebut disebabkan oleh karyawan perusahaan yang menipu konsumen saat melaksanakan pekerjaannya sehingga merugikan konsumen. Konsumen yang merasa dirugikan oleh perusahaan tentu akan meminta pertanggung jawaban kepada perusahaan, konsumen tidak memperdulikan siapa pihak yang bersalah atau tidak dalam penyebab kerugiannya tersebut, konsumen hanya mengetahui bahwa dia harus meminta pertanggung jawaban kepada perusahaan tempatnya membeli barang/jasa yang dikonsumsinya.

Di dalam prinsip-prinsip tanggung jawab kita mengenal salah satu prinsip yaitu prinsip tanggung jawab berdasarkan unsur kesalahan, prinsip ini dapat kita kaitkan dengan kesalahan karyawan yang merugikan konsumen, yang di mana dalam prinsip ini menyatakan bahwa seseorang baru dapat di mintakan pertanggung jawabannya secara hukum apabila ada unsur kesalahan yang di lakukannya. Di 
dalam Pasal 1365 BW yang mengatur perbuatan melanggar hukum mengharuskan terpenuhinya empat unsur pokok perbuatan melanggar hukum, yaitu:

a. Adanya perbuatan;

b. Adanya unsur kesalahan;

c. Adanya kerugian yang diderita;

d. Adanya hubungan kausalitas antara kesalahan dan kerugian.

Jika dilihat dari empat unsur pokok perbuatan melanggar hukum di atas, tentu hal ini dapat dikaitkan dengan perbuatan karyawan yang melanggar hukum sehingga berdampak kerugian pada konsumen.

Pasal 1365 BW merupakan pijakan yang sangat kokoh dalam upaya pengembalian kerugian yang timbul oleh karena terjadinya fraud yang dilakukan karyawan, berulangkali dibahas pada bab sebelumnya mengenai inti dari Pasal 1365 BW di mana, siapapun dan apapun itu, ketika menimbulkan suatu kerugian atas pihak lainnya maka kepadanya dapat dimintai pertanggungjawaban. Dari pembahasan bab sebelumnya, atas kerugian yang timbul berdasarkan Pasal 1365 ini, terdapat instrumen hukum perdata yang bisa dipakai untuk memulihkan kerugian, yaitu melalui gugatan atas perbuatan melanggar hukum, atau pembuatan perjanjian pembayaran kerugian (settlement) yang dilengkapi dengan perjanjian jaminan kebendaan. Jika dilihat dari praktek perusahaan dewasa ini, jika terjadi fraud, maka perusahaan cenderung reluctant untuk membawa masalah ini sampai ke pengadilan, dengan sebab-sebab sebagaimana disampaikan pada bab II. Oleh karena itu, penting sekali bagi perusahaan memiliki suatu sistem pengendalian atas fraud yang komprehensif, sehingga tidak banyak membuang sumber daya perusahaan dalam hal waktu, orang dan uang untuk berperkara, apalagi jika kerugian yang dihadapi tidak sebesar dengan perkiraan biaya berperkara.

Berbicara mengenai sistem pengendalian fraud, banyak sekali teori dan jurnal serta pembahasan mengenai fraud preventation system dalam kerangka tata kelola perusahaan yang baik, namun sangat menggelitik bahwa sangat sulit didapatkan scholar yang membahas fraud recovery system. Pembentuk undang-undang memang telah menyediakan instrumen hukum untuk pemulihan kerugian, namun mengapa tidak terintergrasi dalam good corporate governance 
suatu perusahaan, apakah good di sini karena belum sebagus great atau bahkan sesempurna best. Mungkin.

Jika sekarang adalah era disruptif yang menuntut perusahaan untuk bekerja cepat, tepat, dan hebat, maka jika suatu sistem pengendalian yang berkaitan dengan ekonomi perusahaan belum mampu menjawab tantangan tersebut, maka perusahaan akan sedikit banyak tergerus oleh pesaing. Daripada memikirkan permasalahan dan perkara hukum, seharusnya fraud secara otomatis dapat terselesaikan dengan cepat dan tepat, clean and clear, agar manajemen perusahaan lebih banyak memiliki waktu untuk melakukan inovasi dan memikirkan strategi pengembangan perusahaan, alihalih memikirkan penyelesaian kerugian perusahaan akibat fraud yang dilakukan oleh karyawan.

Perlu solusi untuk hal tersebut, bukan hanya menilai ketiadaan fraud recovery system sebagai masalah, namun dapat pula melihat bahwa ketiadaan atas hal ini sebagai suatu tantangan untuk berinovasi dan melakukan plan, do, check action yang tepat. Beberapa hal yang bisa dilakukan, bertalian dengan kajian teoritikal dan pembahasan bab sebelumnya, perusahaan dapat membuat fraud recovery system dalam suatu tata laksana kerja dengan menggabungkan beberapa instrumen hukum sebagai berikut:

Perusahaan membuat instrumen hukum berupa tata laksana kerja yang berupa: (i) fraud prevention system yang berisi fraud identification, fraud prevention, analisa risiko dan dampak fraud, dan dapat pula mengintegrasikan fraud prevention ini ke dalam perjanjian kerja atau perjanjian kerja bersama antara perusahaan dan karyawan yang memuat kewajiban menghindari dan melakukan fraud oleh karyawan dan konsekuensi atas fraud; (ii) fraud recovery system yang berisi langkah-langkah yang harus ditempuh dan dokumen-dokumen yang harus dibuat jika terjadi fraud untuk penyelesaian kerugian perusahaan akibat fraud.

Berbicara mengenai langkah-langkah yang harus ditempuh dan dokumen yang harus dibuat jika terjadi fraud, maka akan dijabarkan sebagai berikut:

Pertama, begitu fraud dan kerugian telah terjadi dan teridentifikasi sebagai bagian dari fraud identification dalam fraud prevention system, maka perusahaan 
akan melakukan tindakan yang berupa: (i) mencatatkan kerugian dan penghitungan kerugian (termasuk unsur-unsur penyebab kerugian) ke dalam suatu dokumen yang ditandatangani bersama oleh perusahaan dan karyawan, jika perlu telah dilakukan penghitungan oleh pihak ketiga (auditor eksternal). Hal ini untuk mempagari agar jika ternyata harus dibawa ke pengadilan pun, pembuktian adanya kerugian dan nilai kerugian sudah tidak perlu panjang lagi; (ii) membuat perjanjian yang berisi pernyataan berhutang oleh karyawan atas kerugian dalam angka (i) di atas,

Kedua, dapat pula meminjam pembahasan tentang jaminan kebendaan, di mana peran perjanjian jaminan kebendaan dapat ditawarkan.

\section{Kesimpulan}

Dalam hal instrumen hukum untuk penggantian kerugian perusahaan dengan mengajukan gugatan atas perbuatan melanggar hukum ke pengadilan dengan penjelasan sebagaimana di atas, namun banyak perusahaan cenderung untuk melakukan penyelesaian secara internal, yang notabene dengan memakai perangkat hukum yang kurang memadai (dengan perjanjian pembayaran tanpa perjanjian jaminan atau sebatas surat pernyataan membayar oleh karyawan), daripada melakukan penyelesaian di pengadilan, ataupun menggunakan instrumen hukum lain yang tersedia. Hal ini dipengaruhi oleh beberapa faktor, menurut pengalaman yang ada, yaitu: Pertama adalah rendahnya pengetahuan perusahaan dan karyawan atas hukum pada umumnya, atau hukum yang mengatur masalah ganti kerugian pada khususnya, sehingga aturan internal perusahaan pada umumnya tidak mengatur bagaimana karyawan harus mengganti kerugian perusahaan.

Kedua adalah pengaturan ganti kerugian dalam tata kelola perusahaan, di mana fraud control system belum ditetapkan secara hulu ke hilir, dalam artian bahwa upaya kontrol perusahaan hanya sebatas menetapkan apa itu fraud, unsurunsur fraud, serta sanksi adminitrasi atas fraud namun belum sampai mengatur ganti kerugian oleh karyawan dalam hal yang bersangkutan melakukan fraud. Ketiga adalah prosedur cara penghitungan ganti kerugian dalam perusahaan, di mana perusahaan belum mengenali bagaimana cara perhitungan ganti kerugian 
yang dapat dipertanggungjawabkan di muka pengadilan. Dalam mengajukan ganti kerugian atas perbuatan karyawan, perusahaan umumnya mengajukan melalui gugatan atas perbuatan melawan hukum, namun lebih memilih menyelesaikan secara internal dengan prosedur yang bisa dibilang belum mempertimbangkan instrumen hukum yang tersedia.

Dalam Pasal 1365 BW di mana, siapapun dan apapun itu, ketika menimbulkan suatu kerugian atas pihak lainnya maka kepadanya dapat dimintai pertanggungjawaban, dan dalam Pasal 1365 ini, terdapat instrumen hukum perdata yang bisa dipakai untuk memulihkan kerugian, yaitu melalui gugatan atas perbuatan melanggar hukum, atau pembuatan perjanjian pembayaran kerugian (settlement) yang dilengkapi dengan perjanjian jaminan kebendaan dan jika dilihat dari praktek perusahaan dewasa ini, jika terjadi fraud, maka perusahaan cenderung reluctant untuk membawa masalah ini sampai ke pengadilan. Oleh karena itu, penting sekali bagi perusahaan memiliki suatu sistem pengendalian atas fraud yang komprehensif, sehingga tidak banyak membuang sumber daya perusahaan dalam hal waktu, orang dan uang untuk berperkara, apalagi jika kerugian yang dihadapi tidak sebesar dengan perkiraan biaya berperkara.

Instrumen Pemulihan Kerugian Perusahaan atas fraud karyawan dalam perspektif tata kelola perusahaan yaitu Perusahaan membuat instrumen hukum berupa tata laksana kerja yang berupa, fraud prevention system yang berisi fraud identification, fraud prevention, analisa risiko dan dampak fraud, dan dapat pula mengintegrasikan fraud prevention ini ke dalam perjanjian kerja atau perjanjian kerja bersama antara perusahaan dan karyawan yang memuat kewajiban menghindari dan melakukan fraud oleh karyawan dan konsekuensi atas fraud, dan fraud recovery system yang berisi langkah-langkah yang harus ditempuh dan dokumen-dokumen yang harus dibuat jika terjadi fraud untuk penyelesaian kerugian perusahaan akibat fraud. 


\section{Daftar Bacaan}

\section{Buku}

Agus Yudha Hernoko, Hukum Perjanjian Asas Proporsionalitas Dalam Kontrak Komersial (Prenada Media Group 2014).

Arif Arryman et.al, Mengupas Benang Kusut, Merajut Masa Depan (Transformasi Tata Kelola Pelaporan Keuangan Telkom Pasca SOA 2010).

Association of certified fraud examiners (ACFE), "What Is Fraud"” (Association of certified fraud examiners (ACFE), 2017).

Departemen Pendidikan Nasional, Kamus Besar Bahasa Indonesia (4th edn, Gramedia Pustaka Utama 2008).

Moch. Isnaeni, Pengantar Hukum Jaminan Kebendaan (LaksBang PRESSindo 2017).

Munir Fuady, Perbuatan Melawan Hukum (Pendekatan Kontemporer) (Citra Aditya Bakti 2005).

Niewenhuis MJH, Pokok Pokok Hukum Perikatan (Surabaya 1985).

Sarwirini dan Budi Kagramanto, Puspa Ragam Informasi Dan Problematika Hukum (Karya Abditama 2000).

Satrio J, Hukum Jaminan, Hak Jmainan Kebendaan (4th edn, Citra Adtya Bakti 2002).

Trisadini Prasastinah Usanti dan Leonora Bakarbessy, Hukum Jaminan (Revka Petra Media 2016).

Zaeni Asyhadie, Hukum Bisnis Prinsip Dan Pelaksanaannya Di Indonesia (RajaGrafindo Persada (Rajawali Perss) 2012).

\section{Jurnal}

Evalina Yessica, 'Karakteristik Dan Kaitan Antara Perbuatan Melawan Hukum Dan Wanprestasi' (2014) 1 Repertorium.

Siti Kotijah, 'Tanggung Gugat Hukum PerusahaanAkibatPengelolaan Pertambangan Batubara' (2011) 26 Yuridika.

\section{Laman}

Harry Andrian Simbolon, 'Mengupas Seluk Beluk Fraud Dan Cara Mengatasinya' 
(Akuntansiterapan.com, 2010) < <ttps://akuntansiterapan.com/2010/12/22/ mengupas-seluk-beluk-fraud-dan-cara-mengatasinya/ $>$ accessed 1 August 2019.

HOW TO CITE: Dimas Setio Wicaksono, 'Instrumen Pemulihan Kerugian Perusahaan terhadap Fraud Karyawan' (2019) Vol. 2 No. 3 Notaire. 